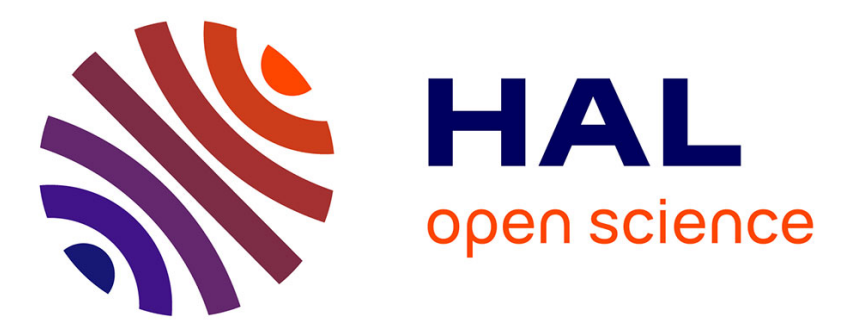

\title{
Identification of traits implicated in the rhizosphere competence of fluorescent pseudomonads: description of a strategy based on population and model strain studies
}

Xavier Latour, Sandrine Delorme, Pascal Mirleau, Philippe P. Lemanceau

\section{- To cite this version:}

Xavier Latour, Sandrine Delorme, Pascal Mirleau, Philippe P. Lemanceau. Identification of traits implicated in the rhizosphere competence of fluorescent pseudomonads: description of a strategy based on population and model strain studies. Agronomie, 2003, 23 (5-6), pp.397-405. 10.1051/agro:2003015 . hal-00886191

\author{
HAL Id: hal-00886191 \\ https://hal.science/hal-00886191
}

Submitted on 1 Jan 2003

HAL is a multi-disciplinary open access archive for the deposit and dissemination of scientific research documents, whether they are published or not. The documents may come from teaching and research institutions in France or abroad, or from public or private research centers.
L'archive ouverte pluridisciplinaire HAL, est destinée au dépôt et à la diffusion de documents scientifiques de niveau recherche, publiés ou non, émanant des établissements d'enseignement et de recherche français ou étrangers, des laboratoires publics ou privés. 


\title{
Identification of traits implicated in the rhizosphere competence of fluorescent pseudomonads: description of a strategy based on population and model strain studies
}

\author{
Xavier Latour ${ }^{\mathrm{a}}$, Sandrine Delorme ${ }^{\mathrm{b}}$, Pascal MirleaU ${ }^{\mathrm{b}}$, Philippe LemanceaU ${ }^{\mathrm{b} *}$ \\ a Laboratoire de Microbiologie du Froid - UPRES 2123, Université de Rouen, 55 rue Saint-Germain, 27000 Evreux, France \\ b UMR “Microbiologie et Géochimie des Sols”, INRA-CMSE, BP 86510, 21065 Dijon Cedex, France
}

(Received 26 September 2002; accepted 26 February 2003)

\begin{abstract}
The lack of consistency of the beneficial effects of inoculated fluorescent pseudomonads has often been related to their bad survival in the rhizosphere. In this review, we describe the strategy followed over the last decade to study traits involved in the rhizosphere competence of these bacteria. The diversity of indigenous populations associated with plant roots was first compared to that of populations associated with uncultivated soils in order to identify traits that discriminate these populations. The involvement of these bacterial traits in the rhizosphere competence was then assessed by comparing the competitiveness of a wild-type strain to that of mutants affected in the corresponding phenotypes. Finally, traits shared by populations adapted to the rhizosphere were identified by comparing both the competitiveness in the rhizosphere and the metabolism of a collection of bacterial strains. The data yielded indicated that rhizosphere-competent pseudomonads show a specific metabolism especially characterized by the efficiency of the pyoverdine-mediated iron uptake and by the ability to reduce nitrogen oxides.
\end{abstract}

population / diversity / model strain / mutant / metabolism

Résumé - Identification de caractères impliqués dans la compétence rhizosphérique des Pseudomonas spp. fluorescents : description d'une stratégie basée sur des études de populations et de souche modèle. Le manque de fiabilité des effets bénéfiques déterminés par les Pseudomonas spp. fluorescents inoculés a souvent été attribué à leur mauvaise survie dans la rhizosphère. Au cours de cette synthèse, nous décrivons la stratégie suivie lors des dix dernières années pour étudier les caractères impliqués dans la compétence rhizosphérique de ces bactéries. La diversité des populations indigènes associées aux racines a d'abord été comparée à celle des populations associées à des sols nus. L'implication de ces caractères bactériens dans la compétence rhizosphérique a ensuite été évaluée en comparant la compétitivité d'une souche modèle à celle de mutants affectés dans les phénotypes correspondants. Finalement, des caractères partagés par les populations adaptées à la rhizosphère ont été identifiés en comparant la compétitivité rhizosphérique et le métabolisme d'une collection de souches. Les données recueillies indiquent que les Pseudomonas spp. fluorescents adaptés à la rhizosphère présentent un métabolisme spécifique caractérisé, en particulier, par l'efficacité de leur système d'acquisition du fer basé sur les pyoverdines et par leur aptitude à réduire les oxydes d'azote.

population / diversité / souche modèle / mutant / métabolisme

\section{INTRODUCTION}

Saprophytic fluorescent Pseudomonas spp. constitute an oxidase-positive group, including various species such as Pseudomonas fluorescens, $P$. putida, P. chlororaphis [5, 80] and more recently described species such as, for example, $P$. jessenii [95] or $P$. lini [16]. All bacteria belonging to this group share the ability to produce soluble yellow-green pigments, pyoverdines, which act as siderophores for these bacteria [71]. These microorganisms are considered to be rhizobacteria, since their densities and activities are stimulated in the rhizosphere $[6,36,41,89]$. They are known to synthesize a variety of secondary metabolites $[7,23,48]$. Some of them exert a toxic activity against various pathogenic and deleterious microorganisms, contributing to a reduction in their saprophytic growth (microbial antagonism) [13, 34]. 
Microbial antagonism against pathogenic agents decreases the frequency of root infections and of diseased plants, whereas antagonism against deleterious microorganisms enhances plant growth [87]. Plant growth promotion can also be ascribed to metabolites affecting the plant physiology such as growth substances [33]. Specific bacterial metabolites may elicit defense reactions of the host plant (induced systemic resistance) [94].

Consequently, some fluorescent pseudomonads are known to improve plant health and/or growth $[30,52,56,97]$. They have been shown to play a role in the natural suppressiveness of soils to fusarium-wilts $[1,3]$ and to take-all [12, 61, 81]. Indeed, fluorescent pseudomonads are considered as potential biocontrol agents of soilborne diseases and several studies have demonstrated their efficacy as microbial inoculants [13, $35,51,78,88,91]$. Despite the positive effects reported in these studies, the overall biological control of soilborne diseases achieved by fluorescent pseudomonads is often inconsistent [52, 97]. This inconsistency has been partially associated with inefficient root colonization by the introduced bacteria [87]. Indeed, a clear relationship has been established between suppression of the wheat root disease take-all and that of fusarium-wilts by different strains of fluorescent pseudomonads and the densities of these bacteria in the rhizosphere of the corresponding host plant $[8,84]$. In order to improve the efficacy and the consistency of the biological control, the use of rhizosphere-competent strains is required. To fulfill this requirement, progress must be made in our knowledge of bacterial traits promoting the rhizosphere competence of fluorescent pseudomonads.

When initiating the strategy described in the present review, most of the studies consisted of evaluating the impact of traits expected to be important for root colonization, such as the presence of flagella [20, 39, 86], pili [96], agglutinin [2], membrane lipopolysaccharrides [21], porin OprF [18], protease [79] or phenazines [69]. Evaluation of the involvement of these traits consisted of comparing the survival of a model strain and of the mutant of that strain affected in the phenotype studied. Even though this strategy contributed to progress in the knowledge of the traits promoting rhizosphere competence of the strains studied [62, 64], it also had limitations. Indeed, results obtained with specific strains and experimental conditions could not always be extended to other strains [20, 39, 86]. The differences that were recorded between strains are not surprising considering the high diversity of fluorescent pseudomonads which have been described largely after these differences were first noted $[10,17,40,42,47,55,66,68,74$, 82]. Furthermore, the strategy described above did not reveal the importance of traits other than those expected at first to be involved in rhizosphere competence, which are not necessarily the most relevant. Thus, the knowledge of the bacterial traits involved in rhizosphere competence was necessarily partial. This was already clearly stressed by De Weger et al. [22] when comparing the phenotype of the strain P. fluorescens WCS365 to those of the 20 mutants, obtained by random mutagenesis, showing an impaired root colonization compared with the wild-type strain. Among these 20 mutants, 3 did not present any difference compared with the wild-type strain in the traits expected to be involved in rhizosphere competence, clearly indicating that other unknown traits were involved in the rhizosphere competence of $P$. fluorescens WCS365. Surprisingly, at that time little attention was given to the possible involvement of carbon and energy metabolism of the bacteria in their rhizosphere competence, despite the fact that the characteristics of the rhizosphere are mostly influenced by the release of photosynthetates by the host plant $[65,98]$.

Altogether these observations led us to propose in the early nineties a strategy based both on population and on model strain studies. We first compared the diversity of populations associated with roots and with uncultivated soils in order to discriminate traits expected to be involved in rhizosphere competence in a non-targeted way. The hypotheses, raised from the population studies, were then evaluated by comparing the competitiveness of a wild-type strain and of isogenic mutants affected in the phenotypes discriminating the rhizospheric and soil populations. Besides the emergence of hypotheses, the initial population studies enabled us to select strains representative of the diversity of populations from rhizospheric and bulk soils. The reduced number of strains considered allowed us to compare their metabolism and their competitiveness in the rhizosphere and then to identify traits shared by the rhizosphere-competent populations.

In this review, we describe this strategy developed over the last few years in our group to identify traits involved in the rhizosphere competence of fluorescent pseudomonads.

\section{COMPARISON OF THE DIVERSITY OF POPULATIONS FROM RHIZOSPHERIC AND BULK SOILS}

The first step of our strategy consisted of raising hypotheses on traits possibly involved in the rhizosphere competence of fluorescent pseudomonads in a non-targeted way. For that purpose, the diversity of indigenous populations of fluorescent pseudomonads associated with roots and with uncultivated soil was compared in order to possibly identify discriminating phenotypes assumed to be involved in rhizosphere competence. Since soils are oligotrophic environments whereas the great majority of soilborne microorganisms, including the fluorescent pseudomonads, are heterotrophic, we hypothesized that nutrient competition, and consequently carbon and energy metabolism of bacteria, would play a major role in their adaptation to the rhizosphere. This environment is indeed characterized by the release of a significant part of the photosynthetates that would be more readily used by the microorganism with the most adapted catabolism. This catabolism is based on electron transfers between donors (organic compounds) and acceptors (coenzymes, $\mathrm{Fe}-\mathrm{S}$ proteins, cytochromes, oxygen and nitrogen oxides). Rhizospheric and soil populations were then characterized for their ability to use a wide range of organic compounds and their ability to mobilize iron and to respire nitrogen oxides. More specifically, the ability of the bacterial strains to grow in the presence of one of the 49 sugars, 49 organic acids or 49 amino acids, some of which have been described as a component of the root exudates $[92,93]$, was tested using API strips (BioMerieux). Ferric iron is a cofactor of proteins indispensable to the oxido-reduction processes of the respiratory chain and is thus essential for microbial metabolism. However, the concentration of $\mathrm{Fe}^{3+}$ available to the soilborne microflora is 
very low [57], in such a way that this ion is usually a limiting factor for microbial growth and activity in soil habitats [59]. The ability to mobilize ferric iron of the bacteria was assessed by measuring their Minimal Inhibitory Concentration (MIC) of 8-hydroxiquinolin, a strong iron chelator $[31,54]$. Bacteria able to reduce $\mathrm{NO}_{3}{ }^{-}$(nitrate reducers), and among them those able to produce $\mathrm{N}_{2} \mathrm{O}$ and/or $\mathrm{N}_{2}$ (denitrifiers), were determined by biochemical methods [10].

In order to enhance the possible rhizosphere effect, plants were continuously cultivated for 5 cycles of 8 weeks each in a given soil (Dijon, France) and the bacterial isolations were done on the last culture. The Dijon soil was kept uncultivated and was maintained in the same environmental conditions as the cultivated soil. Furthermore, in order to stress more clearly the plant effect on the soilborne populations, they were isolated along a horizontal gradient (rhizospheric soil, rhizoplane and root tissues). All these experiments were performed with two plant species (Linum usitatissinum L. and Lycopersicon esculentum Mill.). Numerical analysis of the results enabled us to cluster isolates showing a high level of similarity [44].

The data yielded indicate that the plant affects both the structure and diversity of the indigenous soilborne populations of fluorescent pseudomonads. Indeed, some of the phenotypic clusters only included rhizospheric isolates whereas others only included soil isolates, clearly indicating that the rhizospheric isolates show differences in their abilities to use organic compounds compared with those of soil. More precisely, it was shown that the ability to use specific sugars (saccharose, trehalose and xylose), polyols (inositol and sorbitol) and amino acids (citrulline and trigonelline) is more frequent among rhizospheric populations than soil populations [45, 55]. Overall, rhizospheric strains showed a higher similarity than those isolated from bulk soil, indicating that the diversity of the rhizospheric populations was reduced compared with that of the soil populations. This reduced diversity was even more strongly expressed for the endophytic populations. The ability to mobilize iron of the rhizospheric and soil populations was also shown to differ significantly. Indeed, the frequency distribution of the strains in the different MIC differed significantly according to their origin. The rhizospheric populations were mostly distributed into the classes corresponding to the highest concentrations of 8-hydroxiquinolin, indicating that they were more able to mobilize ferric iron in deficiency conditions than soil populations [54]. Finally, the proportion of strains able to respire nitrates was significantly higher in the populations associated with the roots (90 and $82 \%$ in the root tissues of flax and tomato, respectively), than in the uncultivated soil (55\%). Among these strains, the proportion of denitrifiers gradually and significantly increased in the vicinity of tomato roots (44, 68,75 and $94 \%$ in the uncultivated soil, rhizosphere, rhizoplane and root tissues, respectively) and was higher in the flax rhizoplane (66\%) than in the uncultivated soil.

Altogether, these data indicate that plants select specific populations of fluorescent pseudomonads and that compared with soil populations they are (i) more able to mobilize ferric iron; (ii) more frequently nitrate reducers and denitrifiers, and (iii) able to use specific organic compounds as carbon and energy sources.
Since microbial inoculations would be performed on plants growing in various soils, the impact of the soil type on the plant selection towards the indigenous soilborne populations was further assessed. The two plant species were grown in two different soils and the populations were analyzed as described above. The influence of the soil type on the rhizosphere effect was then considered by comparing data collected in two different soils (Dijon and Châteaurenard, France). Although the selection recorded previously in the Dijon soil was checked in the Châteaurenard soil, this selection appeared to differ in the two soils [47]. The populations associated with the roots of a given plant species cultivated in the two soils differed significantly in their ability to use the organic compounds tested. Differences in the indigenous soilborne populations only partly accounted for the variations of the populations associated with a given plant species cultivated in these two soils. Indeed, the variation of the rhizosphere effect determined by the same plant species was shown to differ in the two soils even when their indigenous microflora was destroyed by $\gamma$-irradiation and replaced by the same calibrated community of fluorescent pseudomonads. The rhizosphere effect was more strongly expressed in the Chateaurenard soil and the structure of the populations re-isolated differed significantly in the rhizosphere of the plants cultivated in the Châteaurenard and in the Dijon soil [46]. These data clearly indicate that it was not possible to identify common organic compounds specifically used by fluorescent pseudomonads associated with the roots of plants cultivated in different soils.

In contrast, indigenous populations of fluorescent pseudomonads selected by the two different plant species cultivated in the two soils have in common the ability to efficiently take up iron [54] and to respire nitrogen oxides [11]. From these observations, we thus hypothesized that these two traits might be involved in the rhizosphere competence of fluorescent pseudomonads.

\section{EVALUATION OF THE INVOLVEMENT OF NITRATE REDUCTASE AND PYOVERDINE IN THE RHIZOSPHERE COMPETENCE OF A MODEL STRAIN}

The second step of our strategy consisted, therefore, of assessing the hypotheses referred to above, using a model strain and isogenic mutants of this strain. The P. fluorescens strain C7R12 is a rifampicin-resistant mutant of the strain C7 [28], previously isolated from the rhizosphere of flax cultivated in Châteaurenard soil [54]. This strain was chosen as a model strain since it was shown (i) to be a good denitrifying strain [10]; (ii) to efficiently mobilize the iron [54]; (iii) to be rhizosphere-competent [28], and (iv) to be a biocontrol agent [51]. Fluorescent pseudomonads have evolved an efficient strategy of iron uptake based on the synthesis of the siderophore pyoverdine and its relevant outer membrane receptor [72]. The possible implication of pyoverdine in the ecological competence of $P$. fluorescens C7R12 in soil and the rhizosphere was evaluated using a pyoverdine minus mutant $\left(\mathrm{Pvd}^{-}\right)$obtained by random insertion of the transposon Tn5 [75]. The Tn5 flanking DNA was amplified by inverse PCR and sequenced. The nucleotide sequence was found to show a 
high level of identity with $p v s B$, a pyoverdine synthetase. As expected, the mutant $\mathrm{Pvd}^{-}$was significantly more susceptible to iron starvation than the wild-type strain, despite its ability to produce another unknown siderophore. As with the wildtype strain, the mutant $\mathrm{Pvd}^{-}$was able to incorporate the wildtype pyoverdine and 5 pyoverdines of foreign origin, but at a significantly lower rate despite the similarity of the outer membrane protein patterns of the two strains [77]. The survival kinetics of the wild-type strain and of the mutant $\mathrm{Pvd}^{-}$in bulk and rhizospheric soil were compared in gnotobiotic and non-gnotobiotic conditions. In gnotobiotic conditions, when inoculated separately both strains showed a similar survival in soil and the rhizosphere, suggesting that iron was not a limiting factor. In contrast, when inoculated together, the bacterial competition was favorable to the pyoverdine producer C7R12. The fitness of the mutant $\mathrm{Pvd}^{-}$in the presence of the indigenous microflora, even when coinoculated with C7R12, was assumed to be related to its ability to take up heterologous pyoverdines. Altogether, these results suggest that pyoverdinemediated iron uptake is involved in the ecological competence of the strain P. fluorescens C7R12 [77].

The involvement of nitrogen oxide respiration in the rhizosphere competence of $P$. fluorescens C7R 12 was also assessed by comparing the competitiveness of the wild-type strain with that of a mutant affected in nitrate reductase synthesis $\left(\mathrm{Nar}^{-}\right)$. Nitrate reductase catalyzes the first step of denitrification. The corresponding experiments were performed under gnotobiotic conditions. The $\mathrm{Nar}^{-}$mutant was obtained by site-directed mutagenesis [76]. The selective advantage given by nitrate reductase over the wild-type strain was assessed by measuring the dynamic of the mutant-to-total-inoculant (wild-type strain plus mutant) ratio. The $\mathrm{Nar}^{-}$mutant clearly showed a lower competitiveness than the wild-type strain, indicating that nitrate reductase is important. However, the selective advantage given by nitrate reductase was more strongly expressed under conditions of lower aeration [76]. Comparison of the competitiveness of the $\mathrm{Pvd}^{-}$and $\mathrm{Nar}^{-}$mutants indicated that the competitive advantages given to C7R 12 by nitrate reductase and pyoverdine were similar. A double mutant $\left(\mathrm{Pvd}^{-} \mathrm{Nar}^{-}\right)$, obtained by site-directed mutagenesis of the $\mathrm{Pvd}^{-}$mutant, presented the lowest competitiveness [76].

Altogether, these data indicate the importance of pyoverdine-mediated iron uptake and nitrate respiration on the fitness of the biocontrol agent $P$. fluorescens C7R12. The competitive advantage given to the wild-type strain by pyoverdine and nitrate reductase over the defective mutants was expressed not only in the rhizosphere but also in bulk soil, indicating that these two bacterial traits are implicated in bacterial saprophytic competence in soil environments.

\section{IDENTIFICATION OF BACTERIAL TRAITS SHARED BY RHIZOSPHERE-COMPETENT POPULATIONS}

The conclusions made following the model strain approach described above are obviously only valid for the model strain studied and only concerned two traits. In order to extend our conclusions to populations of fluorescent pseudomonads and to assess the possible involvement of other metabolic activi- ties, we came back to a population approach for the next step of our strategy. In contrast with the first step of the strategy (see Sect. 2) aiming at the identification of traits shared by the populations selected by the plant, we now assessed metabolic characteristics shared by populations adapted to the rhizosphere.

The adaptation to the rhizosphere was evaluated by measuring the competitiveness of the studied populations in the rhizosphere of tomato cultivated in soil, in the presence of the indigenous microflora and microfauna (non-gnotobiotic conditions). The corresponding experiments are very laborintensive and could thus only be performed on a limited number of strains (23 strains). Twenty-one strains came from the selection of one strain from each of the clusters previously defined $[47,55]$ from the 340 strains tested. These 21 strains are thus expected to be representative of the diversity of the larger bacterial collection from which they issue [15]. Two reference strains were added: (i) $P$. fluorescens C7R12, studied in the model strain approach (see Sect. 3), and (ii) $P$. fluorescens A6, known for its ability to promote plant growth [30] and to suppress soilborne diseases [50] (Berta et al., unpublished data). The results obtained with these 23 strains clearly indicate the high diversity of the strains for their competitiveness in the tomato rhizosphere. Indeed, the survival rate of the strains varied from $0.11 \%$ for the least competitive strain to $61.4 \%$ for the most competitive (Delorme et al., unpublished data).

Relations between these observations and metabolic characteristics already described above - such as the ability to assimilate a wide range of organic compounds and the ability to reduce $\mathrm{NO}_{3}{ }^{-}$and/or $\mathrm{N}_{2} \mathrm{O}$, and additional traits such as the ability to synthesize extracellular enzymes (gelatin liquefaction and levan production) [49], to synthesize $\mathrm{N}$-acyl-homoserine-lactones (NAHL) involved in quorum sensing [26], to synthesize phenazines (antibiotic compounds) [83], and the characterization of the pyoverdine-mediated iron uptake (siderotype and ability to incorporate heterologous pyoverdines) [73] - were evaluated by appropriate statistical methods. Multiple correspondence analyses were first applied to identifying possible traits explaining the bacterial competitivity, and were then followed by mean multiple comparisons and variance analyses to determine if these traits were indeed involved in the rhizosphere competence of the fluorescent pseudomonads [15].

These statistical analyses indicated that the populations selected by the plant were more competitive than the populations isolated from bulk soils. However, some strains isolated from the rhizosphere were not necessarily competitive in this environment, thus confirming the relevance of the competitivity experiments developed by Delorme et al. (unpublished data).

Except for one strain, the most competitive strains all belonged to the same siderotype, which was different from that of the less competitive strains, showing various other siderotypes. The only strain differing by its siderotype from the other competitive strains also differed from these strains by its ability to synthesize NAHL and phenazine. The most competitive strains were all able to reduce nitrogen oxides to dinitrogen gas. In contrast, the most competitive strains did 
not belong to the same phenotypic clusters, indicating that these strains could not be differentiated from the less competitive on the basis of their auxanogram. The only electron donors used in common by the most competitive strains was trehalose. Altogether, these data clearly show the importance of carbon and energy metabolism and more especially of specific electron acceptors (ferric iron and nitrogen oxides) in the rhizosphere competence of the fluorescent pseudomonads.

All the most competitive strains had gelatinase. Half of them produced levansucrase, whereas none of the less competitive strains showed this ability. These enzymes contribute to modifications of the root environment which may be favorable for bacterial survival in the rhizosphere. Indeed, the activity of gelatinase, a protease with a broad spectrum, leads to the release of essential amino acids and thus contributes to their increased availability for the bacteria $[14,90]$. In the same way, the synthesis of levan, a polymer of the fructose known to be present in the rhizosphere, contributes to the aggregation of soil adhering to roots and thus favors a more porous structure in rhizosphere soil [4].

Concerning bacterial secondary metabolism, statistical analyses of the data indicated that the ability to produce NAHL explains the rhizosphere competence of the fluorescent pseudomonads tested. The only strain producing phenazine, also showing the ability to synthesize NAHL, appeared to be competitive in the rhizosphere; however, this was not significant since there was only that strain with this ability among those tested.

A major conclusion of this study is that rhizosphere competence has a multifactorial determinism that confirms the limitations of research carried out only on specific traits. As an example, it appeared that (i) the most competitive strains have the ability to use trehalose; (ii) however, some non-competitive strains also show this ability; (iii) but these non-competitive strains do not have the ability to denitrify, and thus (iv) the competitive strains present both the ability to use trehalose and to denitrify [15].

Another major conclusion is that depending on the strains, the strategy of adaptation to the rhizosphere differs. The data yielded allowed us to stress two types of behavior. In the first one, the strains show a specific carbon and energy metabolism. They share the same siderotype, they are able to fully reduce nitrogen oxides and they have the ability to assimilate trehalose and to produce gelatinase. The competitivity of the second type would rather be ascribed to its ability to antagonize the indigenous microflora through the synthesis of an antibiotic (phenazine) and its probable regulation through NAHL production, as described in the strain $P$. aureofaciens 30-84 [99].

\section{DISCUSSION}

This review describes the strategy that we have developed over the last decade in order to identify bacterial traits involved in the rhizosphere competence of fluorescent pseudomonads. The originality of this strategy is to have associated both population and model strain approaches (Fig. 1).
Our study strategy first consisted of comparing indigenous populations associated with roots and bulk soils in order to identify traits allowing the discrimination of these two types of populations, these traits being thus expected to be involved in rhizosphere competence. During these diversity studies, our attention was focused on bacterial carbon and energy metabolism because of the importance of trophic relations among microorganisms, mostly heterotrophic, in soils [53, 58] and rhizospheres $[14,25]$. The diversity studies were conducted in the rhizosphere of two plant species cultivated in two different soils, and in these same soils kept uncultivated. Comparison of the diversity of bacterial populations associated with a given soil and with roots of a given plant species was also performed by Mavingui et al. [67] and Frey et al. [29]. And the possible crop specificity towards fluorescent pseudomonads was previously shown by Glandorf et al. [32]. However, to our knowledge, our studies were among the very first to include both the effects of the plant species and of the soil type on the selection achieved by the host plant towards bacterial soil populations. These studies allowed us to identify traits shared by pseudomonad populations selected by two different plant species cultivated in two different soils.

The implication of these traits in rhizosphere adaptation was then evaluated by a model strain approach that consisted of comparing the rhizospheric competitiveness of a wild-type strain with that of mutants. This approach, based on the comparison of the survival kinetics of wild-type strains with that of mutants, affected in specific phenotypes, has been commonly used to assess the involvement of these phenotypes in the rhizosphere competence of various bacterial strains [9, $22,24,36,69]$. However, an originality of our work was to evaluate the relative importance of two bacterial traits thanks to the use of single and double mutants. Another originality was to assess the impact of a specific environmental parameter (soil aeration) on the involvement of the studied traits in the rhizosphere competence of the wild-type strain. The choice of this parameter was made since aeration is known (i) to vary a lot in the rhizosphere, and (ii) to affect bacterial fitness in the rhizosphere [37, 38, 70].

Besides the identification of traits expected to be involved in rhizosphere competence, our early diversity studies enabled us to select strains representative of the populations associated with soils and roots. This reduced number of strains made possible the evaluation of their competitiveness in the rhizosphere. A similar approach based on the selection of strains representative of the diversity, assessed by PCR-RAPD, of the 2,4-diacetylphloroglucinol-producing Pseudomonas spp. enabled Raaijmakers and Weller [82] to select the superior rootcolonizing P. fluorescens Q8r1-96. In our case, the level of competitiveness in the rhizosphere of the selected strains was compared with several characteristics of their metabolism in order to identify traits shared by populations adapted to the rhizosphere. This type of relation was applied by Ellis et al. [27] to identify conserved traits in fluorescent pseudomonads with antifungal activity.

The main conclusion obtained following the strategy developed is that the carbon and energy metabolism of fluorescent pseudomonads plays a major role in their rhizosphere competence. 


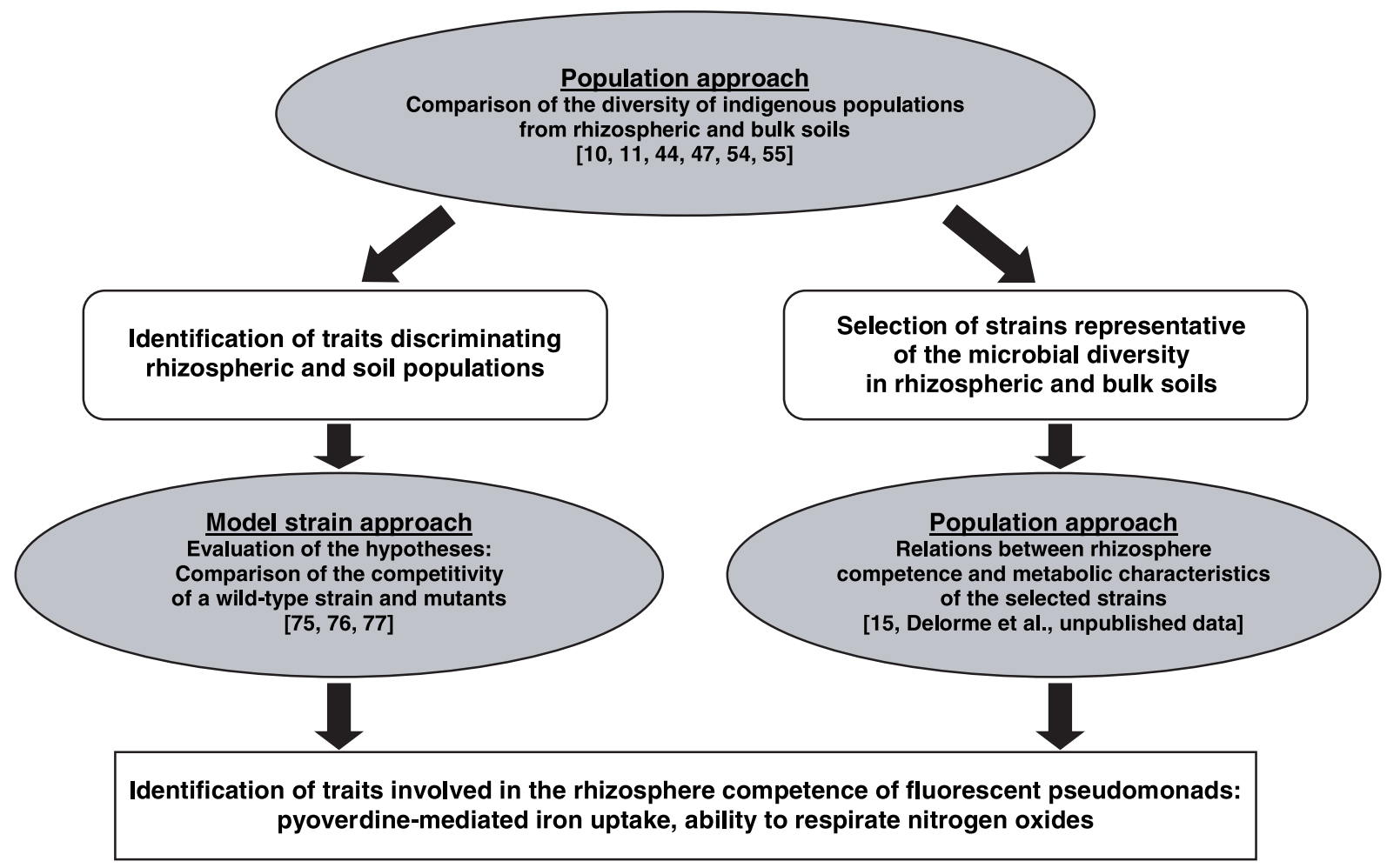

Figure 1. Schematic representation of the approaches followed to identify bacterial traits involved in the rhizosphere competence of fluorescent pseudomonads.

More specifically, our data show the importance of the ability to use ferric iron and nitrogen oxides as electron acceptors in the rhizosphere competence of fluorescent pseudomonads. This conclusion agrees with the fact that (i) fluorescent pseudomonads require oxygen or nitrogen oxides for oxidization of all the substrates, except arginine [45], and that (ii) the ferric iron and oxygen content is usually low in the rhizosphere [37, $38,60]$. The ability to use efficiently both types of electron acceptors is favorable to the respiratory potential of fluorescent pseudomonads. This potential directly affects the assimilation of nutrients by Pseudomonas and, consecutively, their multiplication. Indeed, aerobic respiration and denitrification allow both the production of ATP by oxidative phosphorylation and the reoxidation of $\mathrm{NADH}$ and $\mathrm{FADH}_{2}$ coenzymes. This reoxidation is required for the Krebs cycle that appears to play a major role in pseudomonads' metabolism and, more specifically, in nutrient assimilation by these bacteria [45]. Ecological observations made by Lugtenberg's group on the rhizosphere competence of the model strain $P$. fluorescens WCS365 are in agreement with these metabolic characteristics. Indeed, the ability to use organic acids in the rhizosphere, oxidized by the Krebs cycle, is involved in the rhizosphere competence of this model strain [64], whereas the ability to use sugars by the Entner-Doudoroff pathway does not confer a competitive advantage on this bacterial strain [63].

In fact, from our data it was not possible to identify a common auxanogram shared by the most competitive populations in the rhizosphere. This observation could be related to the ability of the pseudomonads to use a wide range of organic compounds which would thus allow them to adapt their metabolism to various environments, and more specifically, to the evolution of composition of the root exudates according to the plant species, the plant development and the soil type.

Despite the progress made in the knowledge of the bacterial traits involved in the rhizosphere competence of fluorescent pseudomonads, our study strategy presents limitations. The first one is that only metabolic traits, mostly related to carbon and energy metabolism of bacteria, were taken into account. Relations other than trophic between the microflora and the host plant may probably also play a role in the rhizosphere competence of the fluorescent pseudomonads: molecular recognition through signal molecules and/or membrane characteristics [19, 25], the ability to stand or detoxify toxic compounds, etc. A second limitation is that even if the number of traits tested were significant during the population studies, they still remain quite low and, moreover, were chosen a priori. Other strategies than the one described in the present review were aimed at searching for untargeted traits involved in the rhizosphere competence of model strains, following an approach based on random mutagenesis to identify genes targeted by the insertion sequence in mutants showing an impaired root colonization $[43,62]$ or to identify genes preferentially expressed in the rhizosphere [85].

Development of functional genomic and proteomic methods should allow us to provide new insights into the microbial determinism of rhizosphere competence. Further 
research should also take into more consideration the effect of the host plant in the plants-microorganisms interaction, and plant traits affecting the rhizosphere microflora should also be determined. The final goal would be to identify the most favorable plant/microbe couples for the survival and activity of the beneficial introduced organisms.

Acknowledgements: The authors are grateful to K. Klein for correcting the English text.

\section{REFERENCES}

[1] Alabouvette C., Lemanceau P., Natural suppressiveness of soils in management of fusarium wilts, in: Utkhede R., Gupta V.K. (Eds.), Management of soil-borne diseases, Kalyani publisher, Ludhiana, India, 1996, pp. 301-322.

[2] Anderson A.J., Habibzadegah-Tari P., Tepper C.S., Molecular studies on the role of a root surface agglutinin in adherence and colonization by Pseudomonas putida, Appl. Environ. Microbiol. 54 (1988) 375-380.

[3] Baker R., Elad Y., Sneh B., Physical, biological and host factors in iron competition in soils, in: Swinburne T.R. (Ed.), Iron, siderophores and plant diseases, Plenum press, New York and London, 1986, pp. 77-84.

[4] Bezzate S., Aymerich S., Chambert R., Czarnes S., Berge O., Heulin T., Disruption of the Paenibacillus polymyxa levansucrase gene impairs its ability to aggregate soil in the wheat rhizosphere, Environ. Microbiol. 2 (2000) 333-342.

[5] Bossis E., Lemanceau P., Latour X., Gardan L., The taxonomy of Pseudomonas fluorescens and P. putida: current status and need for revision, Agronomie 20 (2000) 51-63.

[6] Bowen G.D., Rovira A.D., Microbial colonization of plant roots, Annu. Rev. Phytopathol. 14 (1976) 121-144.

[7] Budzikiezwicz H., Secondary metabolites from fluorescent pseudomonads, FEMS Microbiol. Rev. 104 (1993) 209-228.

[8] Bull C.T., Weller D.M., Thomashow L.S., Relationship between root colonization and suppresssion of Gaeumannomyces graminis var. tritici by Pseudomonas fluorescens strain 2-79, Phytopathology 81 (1991) 954-959.

[9] Carroll H., Moënne-Loccoz Y., Dowling D.N., O'Gara F., Mutational disruption of the biosynthesis genes coding for the antifungal metabolite 2,4-diacetylphloroglucinol does not influence the ecological fitness of Pseudomonas fluorescens F113 in the rhizosphere of sugarbeets, Appl. Environ. Microbiol. 61 (1995) 3002-3007.

[10] Clays-Josserand A., Lemanceau P., Philippot L., Lensi R., Influence of two plant species (flax and tomato) on the distribution of nitrogen dissimilative abilities within fluorescent Pseudomonas spp., Appl. Environ. Microbiol. 61 (1995) 1745-1749.

[11] Clays-Josserand A., Ghiglione J.F., Philippot L., Lemanceau P., Lensi R., Effect of soil type and plant species on the fluorescent pseudomonads nitrate dissimilating community, Plant and Soil 209 (1999) 275-282.

[12] Cook R.J., Rovira A.D., The role of bacteria in biological control of Gaeumannomyces graminis by suppressive soils, Soil. Biol. Biochem. 8 (1976) 269-273.

[13] Cook R.J., Thomashow L.S., Weller D.M., Fujimoto D., Mazzola M., Bangera G., Kim D.S., Molecular mechanisms of defense by rhizobacteria against root disease, Proc. Natl. Acad. Sci. USA 92 (1995) 4197-4201.

[14] Curl E.A., Truelove B., The rhizosphere, in: Advances series in agricultural sciences No. 15, Springer-Verlag, Berlin, Heidelberg, New York, Tokyo, 1986.

[15] Delorme S., Caractères bactériens associés à la compétitivité des Pseudomonas spp. fluorescents dans la rhizosphère, Thèse de Doctorat, Université de Bourgogne, Dijon, 2001.
[16] Delorme S., Lemanceau P., Christen R., Corberand T., Meyer J.M., Gardan L., Pseudomonas lini sp. nov., a novel species from bulk and rhizospheric soils, Int. J. Syst. Bacteriol. 52 (2002) 513 523.

[17] Delorme S., Philippot L., Edel-Hermann V., Deulvot C., Mougel C., Lemanceau P., Compared genetic diversity of the narG, nosZ and 16S rRNA genes in fluorescent pseudomonads, Appl. Environ. Microbiol. 69 (2003) 1004-1012.

[18] De Mot R., Vanderleyden J., Purification of a root-adhesive outer membrane protein of root-colonizing Pseudomonas fluorescens, FEMS Microbiol. Lett. 81 (1991) 323-328.

[19] Dénarié J., Debelle F., Prome J.C., Rhizobium lipo-chitooligosaccharide nodulation factors: signaling molecules mediating recognition and morphogenesis, Ann. Rev. Biochem. 65 (1996) 503535 .

[20] De Weger L.A., Van Der Vlught C.I.M., Wijfjes A.H.M., Bakker P.A.H.M., Lugtenberg B.J.J., Flagella of a plant-growth-stimulating Pseudomonas fluorescens strain are required for colonization of potato roots, J. Bacteriol. 169 (1987) 2769-2773.

[21] De Weger L.A., Bakker P.A.H.M., Schippers B., Van Loosdrecht M.C.M., Lugtenberg B.J.J., Pseudomonas spp. with mutational changes in the $\mathrm{O}$-antigenic side chain of their lipopolysaccharide are affected in their ability to colonize potato roots, in: Lugtenberg B.J.J. (Ed.), Signal molecules in plants and plant-microbe interactions, Berlin, Springer-Verlag, 1989, pp. 197-202.

[22] De Weger L.A., Van Der Bij A.J., Dekkers L.C., Simons M., Wijffelman C.A., Lugtenberg B.J.J., Colonization of the rhizosphere of crop plants by plant-beneficial pseudomonads, FEMS Microbiol. Ecol. 17 (1995) 221-228.

[23] Dowling D.N., O'Gara F., Metabolites of Pseudomonas involved in the biocontrol of plant disease, Trends Biotechnol. 12 (1994) 133-140.

[24] Duijff B.J., Gianinazzi-Pearson V., Lemanceau P., Involvement of the outermembrane lipopolysaccharides in the endophytic root colonization of tomato roots by biocontrol Pseudomonas fluorescens strain WCS417r, New Phytol. 135 (1997) 325-334.

[25] Duijff B.J., Recorbet G., Bakker P.A.H.M., Loper J.E. Lemanceau P., Microbial antagonism at the root level is involved in the suppression of Fusarium wilt by the combination of nonpathogenic Fusarium oxysporum Fo47 and Pseudomonas putida WCS358, Phytopathology 89 (1999) 1073-1079.

[26] Elasri M., Delorme S., Lemanceau P., Stewart G., Laue B., Glickmann E., Oger P.M., Dessaux Y., Acyl-homoserine lactone production is more common among plant-associated Pseudomonas spp. than among soilborne Pseudomonas spp., Appl. Environ. Microbiol. 67 (2001) 1198-1209.

[27] Ellis J.E., Timms-Wilson T.M., Bailey, M.J., Identification of conserved traits in fluorescent pseudomonads with antifungal activity, Environ. Microbiol. 2 (2000) 274-284.

[28] Eparvier A., Lemanceau P., Alabouvette C., Population dynamics of non-pathogenic Fusarium and fluorescent Pseudomonas strains in rockwool, a substratum for soilless culture, FEMS Microbiol. Ecol. 86 (1991) 177-184.

[29] Frey P., Frey-Klett P., Garbaye J., Berge O., Heulin T., Metabolic and genotypic fingerprinting of fluorescent pseudomonads associated with the Douglas Fir-Laccaria bicolor mycorrhizosphere, Appl. Environ. Microbiol. 63 (1997) 1852-1860.

[30] Gamalero E., Martinotti M.G., Trotta A., Lemanceau P., Berta G., Morphogenetic modifications induced by Pseudomonas fluore scens A6RI and Glomus mossea BEG12 in the root system of tomato differ according to plant growth conditions, New Phytol. 155 (2002) 293-300.

[31] Geels P., Schippers B., Reduction of yield depression in high frequency potato cropping soil after seed tuber treatment with antagonistic fluorescent Pseudomonas spp., Phytopathol. Z. 108 (1983) 207-214

[32] Glandorf D.C.M., Peters L.G., Van der Sluis I., Bakker P.A.H.M., Schippers, B., Crop specificity of rhizosphere pseudomonads and the involvement of root agglutinins, Soil Biol. Biochem. 25 (1993) 981-989. 
[33] Glick B.R., The enhancement of plant growth by free-living bacteria, Can. J. Microbiol. 41 (1995) 109-117.

[34] Gutterson N., Microbial fungicides: recent approaches to elucidating mechanisms, Crit. Rev. Biotechnol. 10 (1990) 69-91.

[35] Haas D., Keel C., Laville L., Maurhofer M., Oberhänsli T., Schnider U., Voisard C., Wuthrich B., Défago G., Secondary metabolites of Pseudomonas fluorescens strain CHAO involved in suppression of root diseases, in: Hennecke H., Verma D.P.S (Eds.), Advances in molecular genetics of plant-microbe interactions, Kluwer Academic, Dordrecht, Netherlands, 1991, pp. 450 456.

[36] Höfte M., Boelens J., Verstraete W., Survival and root colonization of mutants of plant growth-promoting pseudomonads affected in siderophore biosynthesis or regulation of siderophore production, J. Plant Nutr. 15 (1992) 2253-2262.

[37] Höjberg O., Sörensen J., Microgradients of microbial oxygen consumption in a barley rhizosphere model system, Appl. Environ. Microbiol. 59 (1993) 431-437.

[38] Höjberg O., Schnider U., Winteler H.V., Sörensen J., Haas D., Oxygen-sensing reporter strain of Pseudomonas fluorescens for monitoring the distribution of low-oxygen habitats in soil, Appl. Environ. Microbiol. 65 (1999) 4085-4093.

[39] Howie W.J., Cook R.J., Weller D.M., Effects of soil matric potential and cell motility on wheat root colonization by fluorescent pseudomonads suppressive to take-all, Phytopathology 77 (1987) 286-292.

[40] Keel C., Weller D.M., Natsch A., Défago G., Cook R.J., Thomashow L.S., Conservation of the 2,4-diacetylphloroglucinol biosynthesis locus among fluorescent Pseudomonas strains from diverse geographic locations, Appl. Environ. Microbiol. 62 (1996) $552-563$

[41] Kluepfel D.A., The behavior and tracking of bacteria in the rhizosphere, Annu. Rev. Phytopathol. 31 (1993) 441-472.

[42] Laguerre G., Rigottier-Gois L., Lemanceau P., Fluorescent Pseudomonas species categorized by using Polymerase Chain Reaction (PCR)/restriction fragment analysis of $16 \mathrm{~S} \mathrm{rDNA}$, Mol. Ecol. 3 (1994) 479-487.

[43] Lam S.T., Ellis D.M., Ligon J.M., Genetic approaches for studying rhizosphere colonization, Plant and Soil 129 (1990) 11-18.

[44] Latour X., Effet de la plante et du sol sur la diversité des populations telluriques de Pseudomonas spp. fluorescents, Thèse de Doctorat, Université de Bourgogne, Dijon, 1996.

[45] Latour X., Lemanceau P., Carbon and energy metabolism of oxidase-positive saprophytic fluorescent Pseudomonas spp., Agronomie 17 (1997) 427-443.

[46] Latour X., Philippot L., Corberand T., Lemanceau P., The establishment of an introduced community of fluorescent pseudomonads in the soil and in the rhizosphere is affected by the soil type, FEMS Microbiol. Ecol. 30 (1999) 163-170.

[47] Latour X., Corberand T., Laguerre G., Allard F., Lemanceau P., The composition of fluorescent pseudomonad populations associated with roots is influenced by plant and soil type, Appl. Environ. Microbiol. 62 (1996) 2449-2456.

[48] Leisinger T., Margraff R., Secondary metabolites of the fluorescent pseudomonads, Microbiol. Rev. 43 (1979) 422-442.

[49] Lelliot R.A., Billing E., Hayward A.C., A determinative scheme for fluorescent plant pathogenic pseudomonads, J. Appl. Bacteriol. 29 (1966) 470-489.

[50] Lemanceau P., Samson R., 1983. Relations entre quelques caractéristiques in vitro de 10 Pseudomonas fluorescents et leur effet sur la croissance du haricot (Phaseolus vulgaris), in: Dubos B.P., Olivier J.M. (Eds.), Les antagonismes microbiens, INRA, Paris, 1983, pp. 327-328.

[51] Lemanceau P., Alabouvette C., Biological control of fusarium deseases by fluorescent Pseudomonas and non-pathogenic Fusarium, Crop Prot. 10 (1991) 279-286.

[52] Lemanceau P., Alabouvette C., Suppression of fusarium wilts by fluorescent pseudomonads: mechanisms and applications, Biocontrol Sci. Technol. 3 (1993) 219-234.
[53] Lemanceau P., Alabouvette C., Couteaudier Y., Recherches sur la résistance des sols aux maladies. XIV. Modification du niveau de réceptivité d'un sol résistant et d'un sol sensible aux fusarioses vasculaires en réponse à des apports de fer et de glucose, Agronomie 8 (1988) 155-162.

[54] Lemanceau P., Samson R., Alabouvette C., Recherches sur la résistance des sols aux maladies. XV. Comparaison des populations de Pseudomonas fluorescents dans un sol résistant et un sol sensible aux fusarioses vasculaires, Agronomie 8 (1988) 243-249.

[55] Lemanceau P., Corberand T., Gardan L., Latour X., Laguerre G., Boeufgras J.M., Alabouvette C., Effect of two plant species, flax (Linum lusitatissinum L.) and tomato (Lycopersicon esculentum Mill.) on the diversity of soilborne populations of fluorescents pseudomonads, Appl. Environ. Microbiol. 61 (1995) 1004-1012.

[56] Lifshitz R., Kloepper J.W., Kozlowsli M., Simonson C., Carlston J., Tipping E.M., Zaleska I., Growth promotion of canola (rapeseed) seedling by a strain of Pseudomonas putida under gnotobiotic conditions, Can. J. Microbiol. 33 (1987) 390-395.

[57] Lindsay W.L., Chemical equilibria in soil, Wiley J. and Sons, New York, 1979.

[58] Lockwood J.L., Soil fungistasis, Ann. Rev. Phytopathol. 2 (1964) 341-362.

[59] Loper J.E., Buyer J.S., Siderophores in microbial interactions on plant surfaces, Mol. Plant-Microbe Interact. 4 (1991) 5-13.

[60] Loper J.E., Henkels M.D., Availability of iron to Pseudomonas fluorescens in rhizosphere and bulk soil with an ice nucleation reporter gene, Appl. Environ. Microbiol. 63 (1997) 99-105.

[61] Lucas P., Sarniguet A., Collet J.M., Lucas M., Réceptivité des sols au piétin-échaudage (Gaeumannomyces graminis var. Tritici) influence de certaines techniques culturales, Soil Biol. Biochem. 21 (1989) 1073-1078.

[62] Lugtenberg B.J.J., Dekkers L.C., What makes Pseudomonas bacteria rhizosphere competent?, Environ. Microbiol. 1 (1999) 9-13.

[63] Lugtenberg B.J.J., Kravchenko L.V., Simons M., Tomato seed and root exudate sugars: composition, utilization by Pseudomonas biocontrol strains and role in rhizosphere colonization, Environ. Microbiol. 1 (1999) 439-446.

[64] Lugtenberg B.J.J., Dekkers L.C., Bloemberg G.V., Molecular determinants of rhizosphere colonization by Pseudomonas, Annu. Rev. Phytopathol. 39 (2001) 461-490.

[65] Lynch J.M., Whipps J.M., Substrate flow in the rhizosphere, Plant and Soil 129 (1990) 1-10.

[66] Mac Spadden Gardener B.B., Schroeder K.L., Kalloger S.E., Raaijmakers J.M., Thomashow L.S., Weller D.M., Genotypic and phenotypic diversity of phlD-containing Pseudomonas strains isolated from the rhizosphere of wheat, Appl. Environ. Microbiol. 66 (2000) 1939-1946.

[67] Mavingui P., Laguerre G., Berge O., Heulin T., Genetic and phenotypic diversity of Bacillus polymyxa in soil and in the wheat rhizosphere, Appl. Environ. Microbiol. 58 (1992) 1894-1903.

[68] Mavrodi O.V., Mac Spadden Gardener B.B., Mavrodi D.V. Bonsall R.F., Weller D.M., Thomashow L.S., Genetic diversity of phlD from 2,4-diacetylphloroglucinol-producing fluorescent Pseudomonas spp., Phytopathology 91 (2001) 35-43.

[69] Mazzola M., Cook R.J., Thomashow L.S., Weller D.M., Pierson L.S. III, Contribution of phenazine antibiotic biosynthesis to ecological competence of fluorescent pseudomonads in soil habitats, Appl. Environ. Microbiol. 58 (1992) 2616-2624.

[70] Meikle A., Amin-Hanjani S., Glover L.A., Killham K., Prosser J.I., Matric potential and the survival and activity of a Pseudomonas fluorescens inoculum in soil, Soil Biol. Biochem. 27 (1995) 881-892.

[71] Meyer J.M., Abdallah M.A., The fluorescent pigment of Pseudomonas fluorescens: biosynthesis, purification and physicochemical properties, J. Gen. Microbiol. 107 (1978) 319-328.

[72] Meyer J.M., Hallé F., Hohnadel D., Lemanceau P., Ratefiarivelo H., Siderophores of Pseudomonas - biological properties, in: Winkelmann G., Van der Helm D., Neilands J.B. (Eds.), Iron 
transport in microbes, plants and animals. Weinheim: VCH, 1987, pp. 188-205.

[73] Meyer J.M., Stintzi A., De Vos D., Cornelis P., Tappe R., Taraz K., Budzikiewicz H., Use of siderophores to type pseudomonads: the three Pseudomonas aeruginosa pyoverdine systems, Microbiology UK 143 (1997) 35-43.

[74] Meyer J.M., Geoffroy V.A., Baida N., Gardan L., Izard D., Lemanceau P., Achouak W., Palleroni N.J., Siderophore typing, a powerful tool for the identification of fluorescent and nonfluorescent pseudomonads, Appl. Environ. Microbiol. 68 (2002) 27452753.

[75] Mirleau P., Rôle de la pyoverdine et de la nitrate réductase dans la compétence rhizosphérique et tellurique de la souche Pseudomonas fluorescens C7R12, Thèse de Doctorat, Université de Bourgogne, Dijon, 2000.

[76] Mirleau P., Philippot L., Corberand T., Lemanceau P., Involvement of nitrate reductase and pyoverdine in competitiveness of Pseudomonas fluorescens strain C7R12 in soil, Appl. Environ. Microbiol. 67 (2001) 2627-2635.

[77] Mirleau P., Delorme S., Philippot L., Meyer J.M., Mazurier S., Lemanceau P., Fitness in soil and rhizosphere of Pseudomonas fluorescens strain C7R 12 compared with a C7R 12 mutant affected in pyoverdine synthesis and uptake, FEMS Microbiol. Ecol. 34 (2000) 35-44.

[78] Moulin F., Lemanceau P., Alabouvette C., Suppression of Pythium root rot of cucumber by a fluorescent pseudomonad is related to reduced root colonization by Pythium aphanidermatum, J. Phytopathol. 144 (1996) 125-129.

[79] O'Sullivan M., Stephens P.M., O'Gara F., Extracellular protease production by fluorescent $P$ seudomonas spp. and the colonization of sugarbeet roots and soil, Soil Biol. Biochem. 23 (1991) 623627.

[80] Palleroni N.J., Gram-negative aerobic rods and cocci: Family I Pseudomonadaceae, in: Krieg N.R., Holt J.G. (Eds.), Bergey's manual of bacteriology, William and Wilkins, Baltimore, 1984, pp. 141-168.

[81] Raaijmakers J.M., Weller D.M., Natural plant protection by 2,4diacetylphloroglucinol-producing Pseudomonas spp. in take-all decline soils, Mol. Plant-Microbe Interact. 11 (1998) 144-152.

[82] Raaijmakers J.M., Weller D.M., Exploiting genotypic diversity of 2,4-diacetylphloroglucinol-producing Pseudomonas spp.: characterization of superior root-colonizing $P$. fluorescens strain Q8r196, Appl. Environ. Microbiol. 67 (2001) 2545-2554.

[83] Raaijmakers J.M., Weller D.M., Thomashow L.S., Frequency of antibiotic producing Pseudomonas spp. in natural environments, Appl. Environ. Microbiol. 63 (1997) 881-887.

[84] Raaijmakers J.M., Leeman M., Van Oorschot M.M.P., Van der Sluis L., Schippers B., Bakker P.A.H.M., Dose-reponse relationships in biological control of Fusarium wilt of radish by Pseudomonas spp., Phytopathology 85 (1995) 1075-1081.
[85] Rainey P., Adaptation of Pseudomonas fluorescens to the plant rhizosphere, Environ. Microbiol. 1 (1999) 243-257.

[86] Scher F.M., Kloepper J.W., Singleton C., Zaleski I., Laliberte M., Colonization of soybean roots by Pseudomonas and Serratia species: relationship to bacteria motility, chemotaxis and generation time, Phytopathology 78 (1988) 1055-1059.

[87] Schippers B., Bakker A.W., Bakker P.A.H.M., Interactions of deleterious and beneficial rhizosphere microorganisms and the effect on cropping practices, Annu. Rev. Phytopathol. 25 (1987) 339358.

[88] Schippers B., Scheffer R.J., Lugtenberg B.J.J., Weisbeek P.J., Biocoating of seeds with plant growth-promoting rhizobacteria to improve plant establishment, Outlook Agric. 24 (1995) 179-185.

[89] Schroth M.N., Hildebrand D.C., Panopoulos N., Phytopathogenic pseudomonads and related plant-associated pseudomonads, in: Ballows A., Trüper H.G., Dworkin M., Harder W., Schleifer K.H. (Eds.), The Prokaryotes, Springers Verlag, New-York, 1992, pp. 3104-3131.

[90] Simons M., Permentier H.P., De Weger L.A., Wijffelman C.A., Lugtenberg B.J.J., Amino acid synthesis is necessary for tomato root colonization by Pseudomonas fluorescens strain WCS365, Mol. Plant-Microbe Interact. 10 (1997) 102-106.

[91] Thomashow L.S., Weller D.M., Role of a phenazine antibiotic from Pseudomonas fluorescens in biological control of Gaeuman nomyces graminis var. tritici., J. Bacteriol. 170 (1988) 3499-3508.

[92] Vancura V., Fluorescent pseudomonads in the rhizosphere of plants and their relation to root exudates, Folia Microbiol. 25 (1980) 108-173.

[93] Vancura V., Plant metabolites in soil, in: Vancura V., Kunc C. (Eds.), Soil Microbial association, Elsevier Amsterdam, 1988, pp. 57-132.

[94] Van Loon L.C., Bakker P.AH.M., Pieterse C.M.J., Systemic resistance induced by rhizosphere bacteria, Ann. Rev. Plant Physiol. 26 (1998) 453-483.

[95] Verhille S., Baida N., Dabboussi F., Izard D., Leclerc H., Taxonomy study of bacteria from natural mineral waters: proposal of Pseudomonas jessenii sp. nov. and Pseudomonas mandelii sp. nov., Syst. Appl. Microbiol. 22 (1999) 45-58.

[96] Vesper S.J., Production of pili (fimbriae) by Pseudomonas fluorescens and a correlation with attachment to corn roots, Appl. Environ. Microbiol. 53 (1987) 1397-1405.

[97] Weller D.M., Biological control of soilborne plant pathogens in the rhizosphere with bacteria, Annu. Rev. Phytopathol. 26 (1988) 379-407

[98] Whipps J.M., Carbon loss from the roots of tomato and pea seedlings grown in soil, Plant and Soil 103 (1987) 95-100.

[99] Wood D.W., Gong F., Daykin M.M., Williams P., Pierson L.S. III, $\mathrm{N}$-acyl-homoserine lactone-mediated regulation of phenazine gene expression by Pseudomonas aureofaciens 30-84 in the wheat rhizosphere, J. Bacteriol. 179 (1997) 7663-7670. 